\title{
The Geological Heritage of Salobreña (South Spain): example of a touristic area
}

\author{
M. Martín-Martín ${ }^{1}$, C. Sanz de Galdeano ${ }^{2}$ and S. Moliner-Aznar ${ }^{1}$
}

${ }^{1}$ Dpt. Ciencias de la Tierra y Medio Ambiente, AP 99 Univ. Alicante, 03080 Alicante (Spain). manuel.martin.m3@gmail.com.

${ }^{2}$ Instituto Andaluz de Ciencias de la Tierra (CSIC- Univ. Granada). Granada (Spain). csanz@ugr.es.

\begin{abstract}
Salobreña consist of a touristic area with a typical Andalusian white town built on a hill and crowned with a Castle from the medieval era of Moors occupation. The urban area is bordered by fields of tropical crops and fruit trees that, together with its location by the sea, confer on Salobreña a beautiful postcard. These features, as a whole, are an attraction for visitors. Although the authorities are very interested in developing the beach tourism and displaying and protecting the historical center of the town, the interest in geological heritage is negligible. So, this paper tries to expose and evaluate the sites of geologic interest recognizable in the area, so that not only tourists and visitors, but also students, are offered more attractions for their visits. 30 sites are proposed as suitable to be considered as geological heritage, organized in three accessible walking itineraries named respectively: Urban, Panoramic and Littoral georoutes. The selected sites display a great variety of geological typologies as structural geology, stratigraphy, sedimentology, geomaterials, petrology, mineralogy, geomorphology and hydrogeology-hydraulics. Avoiding subjectivity, the sites and georoutes have been classified and ranked with a numerical methodology based on recent literature. The Scientific Value (SV), Potential Educational Value (PEV), Potential Touristic Value (PTV) have been quantified by using several criteria in each case. This allows visitors and teachers to select the most suitable route according to their goals. The Degradation Risk (DR) has also been evaluated, giving key geo-conservation actions. This plan can be presented to political and technical managers from Salobreña Town. Finally, some actions are proposed for better conservation of the sites but also to contribute to education and promote cultural tourism. These actions would also favor educational activities for students of all levels in earth science subjects, but also increase economic activity and sustainable development in the area by incorporating cultural visitors.
\end{abstract}

KEYWORDS: South Spain, Salobreña town, Geodiversity Sites, Evaluation, Geological heritage, Touristic area.

The Geological Heritage of Salobreña (South Spain): example of a touristic area

\section{Introduction}

In any geo-conservational strategy, the first and main step is the inventory of geological heritage. Several successive steps (quantitative assessment, conservation, interpretation and promotion, and finally, monitoring of sites) should be given (Brilha 2016). For this purpose, several concepts related to the geological heritage have been defined in recent years as "in situ" (in field) or "ex situ" (conserved in a laboratory or museum) sites: (1) the term "geosite" (GS) for designing in situ sites with scientific value; (2) "geodiversity site" (GD) for in situ sites with educational, touristic and/or cultural interest; (3) "geo-heritage element" for designing ex situ sites with scientific value; (4) "geodiversity element" for ex situ sites with educational, touristic and/or cultural interest; (5). "viewpoint geosite" for in situ sites observables from a remote good observation point of the surrounding landscape allowing the comprehension of a geological feature (Migón and Pijet-Migón 2017); and (6) "geo-morphosite" (Bollati et al. 2013, 2015, 2017, 2018) for in situ sites with geomorphological interest.

UNESCO set up the net of geoparks from 2001 as a tool to promote the sustainable development of areas aimed at conservation of natural and cultural assets and on the promotion of education and geo-tourism, (McKeever et al. 2010). Geoparks founded as well-defined territories with a development plan challenging to integrate the conservation of geological heritage with the preservation of the cultural identity of local communities (Eder and Patzak 2004; Zouros 2004; McKeever et al. 2010). So, in 2004 UNESCO formed the Global Geoparks Network with 25 Geoparks. This number has been increased to nowadays number more than a hundred Geoparks distributed in more than thirty countries. Nowadays, it seems that the best way to ensure adequate protection to an area containing sites of geological heritage is to follow the integrated concept of protection, education and sustainable development proposed by UNESCO. The concepts are based on the sharing of common strategies and best practice for conservation and geo-tourism development; also, in the exchange of knowledge and support of areas with geological heritage around the globe. Any area must highlight the significant scientific, educational and/or touristic value of the geological heritage based on a solid inventory of the sites.

Usually the geoparks are associated with natural areas where a flora-fauna park was previously defined and promoted to conservation (Aoulad-Sidi-Mhend et al. 2019), but sites of geological interest, are not restricted to rural areas. Taking into 
account that most of the population lives within urban centers, valuable geo-heritage examples have also been defined in urban spaces (Rodrigues et al., 2011; Palacio-Prieto, 2015; Pica et al., 2016). So, a new term appears: the "urban geosite" (or "urban geodiversity site"). It can be defined simply as a site of geological interest within a city and may be natural, derived from geological processes or man-made structures where representative types of rocks were used for their construction (Palacio-Prieto, 2015). In recent times some references to urban geo-heritage have been published around the World (Robinson, 1982; Merguerian and Sanders, 1993; Alfaro et al., 2004; MaNally et al., 2010; Rodrigues et al., 2011; Palacio-Prieto, 2015; Auberger et al., 2016; Pica et al., 2016; Chylinska and Kolodziejczyk, 2018; Thornbush and Allen, 2018; Vegas and Díez-Herrero, 2018; Jun-Ting et al., 2019).

The case proposed here belongs to an inhabited and touristic area (Salobreña town), giving geoparks a new perspective. Salobreña town, located in South Spain (Fig. 1), is close to the Sierra Nevada National Park and to Granada (The Alhambra City). Salobreña consists of a typical Andalusian white town located on a hill by the Mediterranean Sea whilst its slopes are upholstered with typical Andalusian white houses. The town is crowned with a Castle from the medieval era of Moor occupation. The hill of
Salobreña is bordered by fields of fruit trees (avocados, custard apples, mangoes, moreover some papayas, medlards, etc), several types of palms, including date palms and fichus, all typical of tropical or warm climates besides other trees of Mediterranean climate, more sparsely distributed, as are the olive, almond, orange, lemon and fig trees and pomegranates, amongst others. Moreover, its location by the sea and surrounded by such tropical vegetation, including many other ornamental species, gives a beautiful postcard for residents or visitors.

The streets and neighborhoods distribution, and even the names of these, have the imprint of the medieval Arab towns. These features, as a whole, are an attraction for tourists who love the Andalusian medieval culture and the urban landscape of the towns of southern Spain. So, two kind of tourist visit the area: sun and beach tourists and cultural tourists. Both possibilities are not exclusive. Now, sun-beach tourists dominate with respect to the cultural ones. The hill and surrounding areas of the town of Salobreña are made of metamorphic and sedimentary rocks where a lot of geomorphological processes intersect (coastal dynamics, fluvial and gravitational instability processes, karstification, etc.) and several sites of geological interest can be proposed of different typologies.

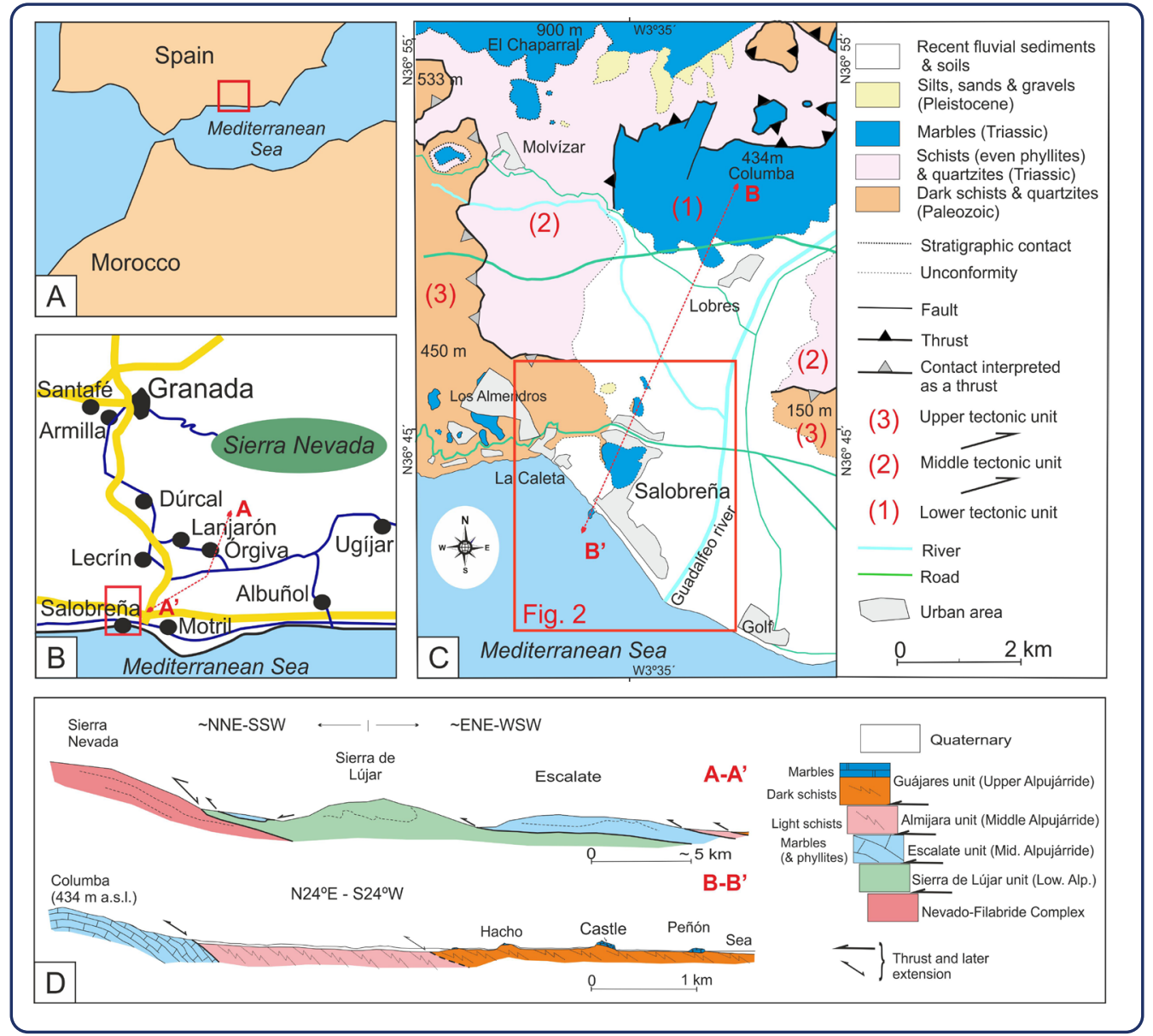

Figure 1: A. Geographic location of the study area in southern Spain; B. Geographic location of the Salobreña area in the Granada province with location of geological cross section A-A'; C. Geological sketch map with location of the Figure 2 and cross section B-B'; D. Geological sketch cross sections reflecting the structure and units of the study area. 
Thus, the great challenge is to announce and conserve this geological heritage but, at the same time, to allow use for scientific, educational and touristic purposes to the scientific community and population. A previous and accurate knowledge of its value is required for the conservation based on specific measures. So, the richness and diversity of the geological heritage of Salobreña is shown in this paper, but also quantitative assessment in order to establish the bases for conservation, education and geo-tourism in a sustainable management way are provided.

\section{Study area}

\section{Geographical, archeological-historical, climatic and biosphere cadre}

The locality of Salobreña is situated in the Mediterranean coast of South Spain, in the province of Granada (Andalusia), 65 $\mathrm{km}$ south of Granada. The center of the town has these geographic coordinates: N36 $6^{\circ} 4^{\prime} 55^{\prime} \mathrm{W} 3^{\circ} 35^{\prime} 0^{\prime} 9^{\prime}$. As can be seen in Fig. 1C, there is a main urban area, on the cited hill. The town has also spread in the plain surrounding the hill in its east and north borders in recent times. The most touristic edifications are located in the south part by the coast to the mouth of the Guadalfeo River. Others urbanized areas are situated to the Northwest, in La Caleta, La Guardia and Los Almendros mountain neighborhoods. The main communication road is the $\mathrm{N}-340$ (Carretera de la Costa), although to the North is the A-7 highway and to the East that of the N-323, which connects with the A-7 and N 340. The town covers an area of approximate $15 \mathrm{~km}^{2}$.

Historically, when the Phoenicians arrived in the area of Salobreña there were already several agricultural and livestock settlements. There they founded their Salambina colony that later passed to the Carthaginians and, of course, later to the Romans. At the beginning of the $8^{\text {th }}$ century the Arabs invaded Hispania and Salobreña passed into their hands. They introduced the cultivation of sugarcane.

Shortly before the capture of Granada, in the year 1489 Salobreña passed into Castilian hands, although later it joined the Moors' rebellion, an insurrection that was stifled a short time later.

The most interesting cultural place is the old Moorish castle built on a rocky hill. This castle was sometimes used as a prison for important people from the kingdom of Granada. At present, several of its parts are in a process of reconstruction and from it there are very good panoramic views, both to the coast and in other directions, even showing the higher mountains of Sierra Nevada. Around this castle, except on its west edge, was formed the old village of Salobreña, with a distribution of streets, in some cases very narrow, with a complete old Arabic distribution.

Owing to the sea, the climatic conditions of Salobreña are not extreme. Usually the winter is warm, some days cool, and in summertime most of the days are hot, but generally do not surpass $30^{\circ} \mathrm{C}$, although the nights can have temperatures above $20^{\circ} \mathrm{C}$. On the whole its weather is nice. The rain fall annual average is of the order of $500 \mathrm{~mm}$, but it is rich in water thanks to the Guadalfeo River, which carries the waters of Sierra Nevada.

Concerning the biosphere, it is interesting to note the presence of extensive cultivations of tropical fruits as has been previously referred to (for this reason this area is called the "Costa Tropical"). These types of fruits were introduced in the last decades and now constitute an exotic characteristic in this area and others of the Granada and Malaga coasts. This is virtually unique in Europe. On the contrary, the traditional crop of the area, the sugar cane, has virtually disappeared. Only the factory is preserved, located in the sector of La Caleta and it still exhibits a large chimney.

The fauna of this area of Granada has no unusual characteristics. It is the norm of the region (rabbit, partridge and less frequently, mountain goat), although being a coastal area there are many flocks of seabirds, different types of seagulls, cormorants and even, although rarely, some gannets. The fish are the usual ones in this area of the Mediterranean.

\section{Geological and geomorphological framework of the Salobreña area}

The area of Salobreña is located in the Betic Cordillera. This cordillera is composed by several domains: the External and Internal zones, the Gibraltar Units, and Neogene intra-mountain basins. Salobreña is situated in the Internal Zone, which is divided in three main domains tectonically superposed, which, from bottom to top, are the Nevado-Filabride, the Alpujarride and the Malaguide complexes (Fig 1D: section A-A'). The first two complexes are formed by metamorphic rocks of previous sediments and igneous rocks (these last in a minor proportion) transformed during the Alpine Orogeny.

In the area of Salobreña and in its immediate surroundings, only the Alpujarride Complex is present (Fig. 1C). In this zone the Alpujarride is formed by three superposed tectonic units (Fig 1D: section B-B'), although in the area cover by the itineraries of this geologic guide only one can be distinguished. The basal rocks correspond to dark schists exhibiting at least two types of micas, black and pink andalusite and well differentiated veins of quartz. Intercalated with these schists there are quartzite levels. All these rocks have been strongly deformed, showing many folds of very different sizes, and at least two schistosities have been affected by many fractures. They are attributed to the Paleozoic.

Over the dark schist there are another type of schists, with lighter aspect, and quartzites. These rocks are well exposed north of Salobreña. However, within the village exposed rock is only visible in a very small outcrop at the beginning of the esplanade called "Paseo de las Flores", under the castle. Their probable age is early Triassic. 
In a higher position are situated the marbles. They are massive, although their foliation can be observed in many places. Owing to the different rheology comparing with the schists, their present contact with them usually is tectonized, and the marbles have slipped on them.

Neither the Nevado-Filabride nor the Malaguide complexes are visible in this area, but the Guadalfeo River has carried many rocks of the first cited complex because this river drains Sierra Nevada. At present it is possible to see in the riverbeds and in the beaches many pebbles of dark schists (other type of dark schists), quartzites, gneisses, amphibolites, light schists with big garnets, marbles, etc. whose origin is the Nevado-Filabride Complex. But at present the Rules Dam has cut this supply of rocks (surely, considering the geological time, this lasted only a moment in the geological evolution of the region).

Over the Alpujarride rocks there are Quaternary sediments, formed by clays, silts, sands and conglomerates with some orange color. They form horizontal beds and are of alluvial origin, probably linked to the paleo-Guadalfeo River. Besides, the present Guadalfeo River and its tributaries present sediments in its beds. The deposits of the beaches are also very recent; in fact they are constantly evolving.

This evolution has been particularly important in this area because, as indicated Jabaloy et al. (2014), the infilling of the coast has been very noticeably, displacing the coast several kilometers to the South in the last centuries.

From the geomorphological point of view, the Guadalfeo River has formed a wide valley and an important delta in its southward progression. But the marbles have resisted partially the erosion, for the moment, and forms the hill on which is situated the castle and the old town, and also the smaller rock called "el Peñón", located between the north and south part of the beach. Before the southward progression of the coastal line this "Peñón" formed a small island. The hill of the castle did not form an island because it was united to the shore by a slightly elevated isthmus.

It is also necessary to point out the existence of big blocks of fallen marbles in the northwestern border of the hill of the castle. This is a phenomenon that surely will continue.

\section{Methodology}

We have proceeded in a classic way (but adapted and restrained to areas close to touristic point of interest and with panoramic and visual relevance) to select the sites of geologic interest that should be the object of promotion. Also, the possible degradation risk and measures for conservation to be adopted have been considered. In a first phase, we have proceeded to the identification of streets, roads, tracks and trails in the village and surroundings areas with geological outcroppings. This phase is followed by the research of sites of geological interest mentioned on touristic guides of the area with landscape and flora-fauna information (turismo@ ayto-salobrena.org; Guía Botánica, 2008) including guides of the plants, birds and strolls.

The field work has followed with the crossing of all streets, roads, tracks and trails to identify and to inventory new possible sites of geological interest. At the sites photograph documentation and sketching have been performed.

The methodology proposed by Brilha (2016) has been applied for the quantitative assessment of the sites. This methodology is based on other works published previously (Bruschi and Cendrero 2009; Reynard 2009; Pereira and Pereira 2010; Bruschi et al. 2011; Pereira and Pereira 2012; Bollati et al. 2013, 2015, 2017). According to Brilha (2016), the evaluation for the sites consists in different criteria grouped in 4 separate parts (Tab. 1). The number of criteria in quantitative assessment must be limited (Bruschi, 2011) since a more accurate result is not warranted with a high number of criteria. The four groups of criteria are: Scientific Value (SV), Potential Educational Use (PEU), Potential Touristic Use (PTU) and Degradation Risk (DR). In this assessment, the parts are evaluated and presented separately and there is not a final ranking (Brilha2016). This procedure allows updating and improving the information collected when sites or regional plans of actuation change in time (Bollati et al. 2013, 2017). Values 1, 2, 3 and 4 are given to each criterion. In the case of Scientific Value, 1, 2 and 4 are only given ( 3 is not used). These values are also weighted (see Table 2) according to a percentage according to Brilha (2016).

Seven criteria based in the representativeness (R), key locality (K1), Scientific knowledge (Sn), Integrity (I), Geological diversity (Gd), Rarity (R) and Use limitations (Ul) delimit the Scientific Value (SV).

Twelve criteria based in the Vulnerability (V), Accessibility (A), Use limitations (U1), Safety (S) Logistics (L), Density of population (Dp), Associations with other values (Av), Scenery (Sc), Uniqueness (U), Observation conditions (Oc), Didactic potential (Dp) and Geological diversity (Gd) are used to valorize the Potential Educational Use (PEU). In this case, vulnerability (V) depends on the possibility of deterioration due to visitors (Fuentes-Gutiérrez and Fernández-Martínez, 2010).

Thirteen criteria are used to valorize the Potential Touristic Use (PTU). Eight of the criteria are also used in the PEU (V, A, Ul, S, L, Dp, Av, Sc, U, Oc). The interpretative potential (Ip), Economical level (El) and Proximity to recreational areas (Pr) are new criteria only used in the PTU.

A combination of factors is the accessibility, dimensions, proximity to villages or cities, touristic or educational assistance and presence or potential threats, give the Degradation Risk (DR) value (Fuentes-Gutiérrez and Fernández-Martínez, 2012). For 
this evaluation we have used five criteria according to Brilha (2016): Deterioration of geological elements (Dg), Proximity to activities potential cause of degradation $(\mathrm{Pa})$, Legal protection (Lp), Accessibility (Ac) and Density of population (Dpp). Already used criteria in the PEU and PTU as favorable (Ac and Dpp) for the DR have a negative sense.

In each part of the evaluation, 0-25 low, 26-50 moderate, 51-75 high, 76-100 very high thresholds, have been used. In this research, the values obtained for the SV are not very high and all the sites have been considered geodiversity sites (GD) with touristic or educational interest.

\section{Results}

Sites of geologic interest and results of the evaluation

The inventory performed has identified a high number of sites of geological interest in the touristic Salobreña area (Fig. 2). The sites can also be classified, according to their typology (Tab. $1)$, in structural geology $(\mathrm{S})$, stratigraphy $(\mathrm{T})$, petrography $(\mathrm{P})$, geomorphology $(\mathrm{G})$, hydrogeology-hydraulics $(\mathrm{H})$ sedimentology (SD), mineralogy (M) and geomaterials (GM). The proposed sites are located along three walking itineraries. These routes with the sites of geological interest have been considered "georoutes" and named: Urban Georoute with 12 sites, Panoramic Georoute with 8 sites and Littoral Georoute with 10 sites (Fig. 2; Tab. 2).

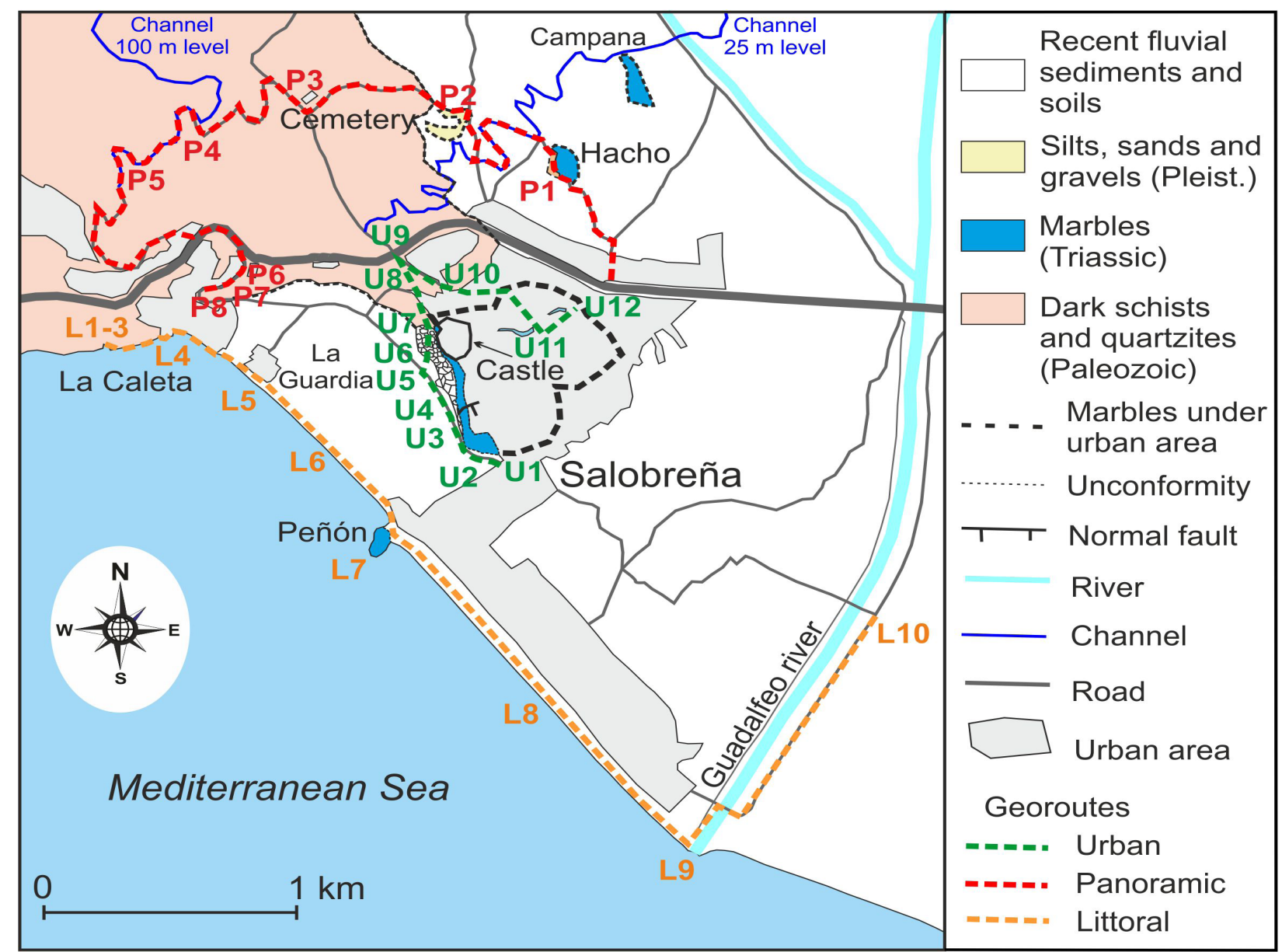

Figure 2: Detailed geological sketch map of the Salobreña area with location of the georoutes and the sites of geological interest.

The scoring performed has revealed 30 sites; all considered geodiversity sites (GD) since the SV never above 75 . On the contrary, values upper to 75 (very high) are obtained in the PEU value, in many of the cases, and in the PTU, in almost all the cases (Tab. 1). Hence, the proposed sites are suitable to be considered geological heritage in the Salobreña area. From the above, 9 can be considered viewpoint geo-diversity sites. On another hand, the Degradation Risk (DR) is very high in 11 cases, high in 18 cases and moderate in 1 case (Fig. 3). 


\begin{tabular}{|c|c|c|c|c|c|c|c|c|c|c|c|c|c|c|c|}
\hline$\square$ & $\mathbf{N}^{\circ}$ & $\begin{array}{l}\text { Name (coordinates of } \\
\text { central point) }\end{array}$ & $\mathbf{T}$ & SV & PEU & PTU & DR & $\begin{array}{l}\text { Geo } \\
\text { route }\end{array}$ & $\mathbf{N}^{\circ}$ & $\begin{array}{l}\text { Name (coordinates of } \\
\text { central point) }\end{array}$ & $\mathbf{T}$ & SV & PEU & PTU & DR \\
\hline \multirow{12}{*}{ 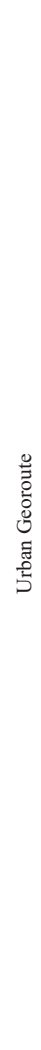 } & U1 & $\begin{array}{c}\text { La Raja Spring } \\
(447488 \mathrm{E} / 4066122 \mathrm{~N})\end{array}$ & $\mathrm{H}$ & $\begin{array}{l}\text { High } \\
(70)\end{array}$ & $\begin{array}{l}\text { Very High } \\
(76.25)\end{array}$ & $\begin{array}{l}\text { Very High } \\
(91.25)\end{array}$ & $\begin{array}{l}\text { High } \\
(73.75)\end{array}$ & \multirow{5}{*}{ 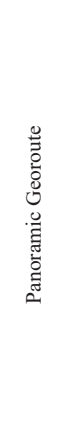 } & P4 & $\begin{array}{l}\text { Schist and Quartzites } \\
(446345 \mathrm{E} / 4067616 \mathrm{~N})\end{array}$ & $\mathrm{P}$ & $\begin{array}{l}\text { Moderate } \\
(48.75)\end{array}$ & $\begin{array}{l}\text { High } \\
(72.50)\end{array}$ & $\begin{array}{l}\text { Very High } \\
(78.75)\end{array}$ & $\begin{array}{l}\text { High } \\
(63.75)\end{array}$ \\
\hline & U2 & $\begin{array}{l}\text { Gambullón Spring } \\
\text { (447369E/4066201N) }\end{array}$ & $\mathrm{H}$ & $\begin{array}{l}\text { Moderate } \\
\quad(40)\end{array}$ & $\begin{array}{l}\text { Very High } \\
\quad(87.5)\end{array}$ & $\begin{array}{l}\text { Very High } \\
(86.25)\end{array}$ & $\begin{array}{l}\text { High } \\
(58.75)\end{array}$ & & P5 & $\begin{array}{c}\text { Salobreña Viewpoint^*}{ }^{\wedge} \\
(446038 \mathrm{E} / 4067265 \mathrm{~N})\end{array}$ & G & $\begin{array}{l}\text { High } \\
(56.25)\end{array}$ & $\begin{array}{l}\text { High } \\
(73.75)\end{array}$ & $\begin{array}{l}\text { Very High } \\
(76.25)\end{array}$ & $\begin{array}{l}\text { High } \\
(72.50)\end{array}$ \\
\hline & U3 & $\begin{array}{c}\text { Salobreña clifs^* } \\
(447326 \mathrm{E} / 4066282 \mathrm{~N})\end{array}$ & $\mathrm{G}$ & $\begin{array}{l}\text { High } \\
(67.5)\end{array}$ & $\begin{array}{l}\text { Very High } \\
(76.25)\end{array}$ & $\begin{array}{l}\text { Very High } \\
(86.25)\end{array}$ & $\begin{array}{l}\text { Very High } \\
(91.25)\end{array}$ & & P6 & $\begin{array}{l}\text { Caleta Sport Area Folds } \\
(446578 \mathrm{E} / 4066941 \mathrm{~N})\end{array}$ & $\mathrm{S}$ & $\begin{array}{l}\text { Moderate } \\
(48.75)\end{array}$ & $\begin{array}{l}\text { Very High } \\
\quad(80)\end{array}$ & $\begin{array}{l}\text { Very High } \\
(83.75)\end{array}$ & $\begin{array}{l}\text { High } \\
(72.50)\end{array}$ \\
\hline & $\mathrm{U} 4$ & $\begin{array}{c}\text { Fallen blocks }{ }^{\wedge} \\
(447296 \mathrm{E} / 4066368 \mathrm{~N})\end{array}$ & $\mathrm{G}$ & $\begin{array}{l}\text { High } \\
(70)\end{array}$ & $\begin{array}{l}\text { Very High } \\
(86.25)\end{array}$ & $\begin{array}{l}\text { Very High } \\
(83.75)\end{array}$ & $\begin{array}{l}\text { High } \\
(58.75)\end{array}$ & & P7 & $\begin{array}{c}\text { Caleta Tower } \\
\text { Viewpoint }{ }^{\wedge *} \\
(446507 \mathrm{E} / 4066903 \mathrm{~N})\end{array}$ & $\mathrm{G}$ & $\begin{array}{l}\text { High } \\
(55)\end{array}$ & $\begin{array}{l}\text { High } \\
(75)\end{array}$ & $\begin{array}{l}\text { Very High } \\
(78.75)\end{array}$ & $\begin{array}{l}\text { Very High } \\
(86.25)\end{array}$ \\
\hline & U5 & $\begin{array}{c}\text { Caves and } \\
\text { speleothems } \\
(447343 \mathrm{E} / 4066416 \mathrm{~N})\end{array}$ & $\mathrm{G}$ & $\begin{array}{l}\text { High } \\
(66.25)\end{array}$ & $\begin{array}{l}\text { Very High } \\
(78.75)\end{array}$ & $\begin{array}{l}\text { Very High } \\
(86.25)\end{array}$ & $\begin{array}{l}\text { Very High } \\
(91.25)\end{array}$ & & P8 & $\begin{array}{l}\text { Sugar Factory Cliff } \\
(446450 \mathrm{E} / 4066853 \mathrm{~N})\end{array}$ & $\mathrm{S}$ & $\begin{array}{l}\text { Moderate } \\
(48.75)\end{array}$ & $\begin{array}{l}\text { High } \\
(75)\end{array}$ & $\begin{array}{l}\text { Very High } \\
(78.75)\end{array}$ & $\begin{array}{l}\text { Very High } \\
(86.25)\end{array}$ \\
\hline & U6 & $\begin{array}{c}\text { Salobreña Fault } \\
(447341 \mathrm{E} / 4466531 \mathrm{~N})\end{array}$ & $\mathrm{S}$ & $\begin{array}{l}\text { High } \\
(55)\end{array}$ & $\begin{array}{l}\text { Very High } \\
(81.25)\end{array}$ & $\begin{array}{l}\text { Very High } \\
\quad(87.5)\end{array}$ & $\begin{array}{l}\text { High } \\
(58.75)\end{array}$ & \multirow{10}{*}{ 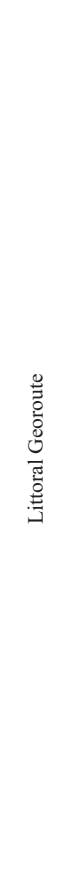 } & $\mathrm{L} 1$ & $\begin{array}{c}\text { Caletón Beach } \\
(445976 \mathrm{E}(4066640 \mathrm{~N})\end{array}$ & $\mathrm{S}$ & $\begin{array}{l}\text { High } \\
(58.75)\end{array}$ & $\begin{array}{l}\text { Very High } \\
(76.25)\end{array}$ & $\begin{array}{l}\text { Very High } \\
(76.25)\end{array}$ & $\begin{array}{c}\text { Moderate } \\
(48.75)\end{array}$ \\
\hline & U7 & $\begin{array}{l}\text { Paseo de las Flores }{ }^{\star *} \\
(447328 \mathrm{E} / 4066671 \mathrm{~N})\end{array}$ & $\mathrm{S}$ & $\begin{array}{l}\text { High } \\
(66.25)\end{array}$ & $\begin{array}{l}\text { Very High } \\
\quad(85)\end{array}$ & $\begin{array}{l}\text { Very High } \\
(86.25)\end{array}$ & $\begin{array}{l}\text { High } \\
(58.75)\end{array}$ & & L2 & $\begin{array}{c}\text { Caletón Cliffs } \\
(446058 \mathrm{E} / 4066658 \mathrm{~N})\end{array}$ & $\mathrm{G}$ & $\begin{array}{l}\text { Moderate } \\
(46.25)\end{array}$ & $\begin{array}{l}\text { High } \\
(73.75)\end{array}$ & $\begin{array}{l}\text { High } \\
(73.75)\end{array}$ & $\begin{array}{l}\text { High } \\
(69.50)\end{array}$ \\
\hline & U8 & $\begin{array}{c}\text { Caracho Ascent } \\
\text { Schists } \\
(447206 \mathrm{E} / 4066827 \mathrm{~N})\end{array}$ & $\mathrm{T}$ & $\begin{array}{l}\text { High } \\
(58.75)\end{array}$ & $\begin{array}{l}\text { Very High } \\
(81.25)\end{array}$ & $\begin{array}{l}\text { Very High } \\
(86.25)\end{array}$ & $\begin{array}{l}\text { Very High } \\
(91.25)\end{array}$ & & L3 & $\begin{array}{l}\text { Caletón Andalucites } \\
(446141 \mathrm{E} / 4066682 \mathrm{~N})\end{array}$ & $\mathrm{M}$ & $\begin{array}{l}\text { High } \\
(70)\end{array}$ & $\begin{array}{l}\text { Very High } \\
(86.25)\end{array}$ & $\begin{array}{l}\text { Very High } \\
(76.25)\end{array}$ & $\begin{array}{l}\text { Very High } \\
\quad(87.5)\end{array}$ \\
\hline & U9 & $\begin{array}{l}\text { Cemetery Crossing } \\
(447086 \mathrm{E} / 4067057 \mathrm{~N})\end{array}$ & $\mathrm{S}$ & $\begin{array}{l}\text { High } \\
(51.25)\end{array}$ & $\begin{array}{l}\text { Very High } \\
\quad(80)\end{array}$ & $\begin{array}{l}\text { Very High } \\
(83.75)\end{array}$ & $\begin{array}{l}\text { Very High } \\
(91.25)\end{array}$ & & L4 & $\begin{array}{c}\text { Lavaderro Square } \\
(446206 \mathrm{E} / 4066689 \mathrm{~N})\end{array}$ & $\mathrm{S}$ & $\begin{array}{l}\text { Moderate } \\
(48.75)\end{array}$ & $\begin{array}{l}\text { Very High } \\
(76.25)\end{array}$ & $\begin{array}{l}\text { Very High } \\
(81.25)\end{array}$ & $\begin{array}{l}\text { High } \\
(68.75)\end{array}$ \\
\hline & U10 & $\begin{array}{l}\text { Postigo Viewpoint }{ }^{*} \\
(447469 \mathrm{E} / 4066656 \mathrm{~N})\end{array}$ & $\mathrm{S}$ & $\begin{array}{l}\text { High } \\
(63.75)\end{array}$ & $\begin{array}{l}\text { Very High } \\
\quad(85)\end{array}$ & $\begin{array}{l}\text { Very High } \\
(88.75)\end{array}$ & $\begin{array}{l}\text { High } \\
(58.75)\end{array}$ & & L5 & $\begin{array}{c}\text { Sugar Factory } \\
\text { Breakwater Viewpoint }{ }^{\wedge} \\
(446428 \mathrm{E} / 4066621 \mathrm{~N})\end{array}$ & $\mathrm{G}$ & $\begin{array}{l}\text { Moderate } \\
(48.75)\end{array}$ & $\begin{array}{l}\text { Very High } \\
(78.25)\end{array}$ & $\begin{array}{l}\text { Very High } \\
(81.25)\end{array}$ & $\begin{array}{l}\text { High } \\
(73.75)\end{array}$ \\
\hline & U11 & $\begin{array}{l}\text { Church Viewpoint }{ }^{\wedge *} \\
(447448 \mathrm{E} / 4066528 \mathrm{~N})\end{array}$ & G & $\begin{array}{l}\text { High } \\
(62.5)\end{array}$ & $\begin{array}{l}\text { Very High } \\
(82.5)\end{array}$ & $\begin{array}{l}\text { Very High } \\
(86.25)\end{array}$ & $\begin{array}{l}\text { High } \\
(58.75)\end{array}$ & & L6 & $\begin{array}{c}\text { La Guardia Beach } \\
(446622 \mathrm{E} / 4066424 \mathrm{~N})\end{array}$ & G & $\begin{array}{l}\text { High } \\
(62.50)\end{array}$ & $\begin{array}{l}\text { High } \\
(71.25)\end{array}$ & $\begin{array}{l}\text { Very High } \\
(81.25)\end{array}$ & $\begin{array}{l}\text { High } \\
(65.00)\end{array}$ \\
\hline & U12 & $\begin{array}{l}\text { Cristo Street Marbles } \\
(447733 \mathrm{E} / 4066799 \mathrm{~N})\end{array}$ & GM & $\begin{array}{l}\text { High } \\
(52.5)\end{array}$ & $\begin{array}{l}\text { Very High } \\
(76.25)\end{array}$ & $\begin{array}{l}\text { Very High } \\
(78.75)\end{array}$ & $\begin{array}{l}\text { High } \\
(73.75)\end{array}$ & & L7 & $\begin{array}{c}\text { Salobreña Crag } \\
(447048 \mathrm{E} / 4065776 \mathrm{~N})\end{array}$ & G & $\begin{array}{l}\text { High } \\
(71.25)\end{array}$ & $\begin{array}{l}\text { Very High } \\
(78.75)\end{array}$ & $\begin{array}{l}\text { Very High } \\
(83.75)\end{array}$ & $\begin{array}{l}\text { Very High } \\
(77.50)\end{array}$ \\
\hline \multirow{3}{*}{ 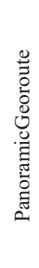 } & P1 & $\begin{array}{c}\text { El Hacho Hill } \\
(447732 \mathrm{E} / 4067405 \mathrm{~N})\end{array}$ & $\mathrm{T}$ & $\begin{array}{l}\text { High } \\
(51.25)\end{array}$ & $\begin{array}{l}\text { Very High } \\
\quad(77.5)\end{array}$ & $\begin{array}{l}\text { Very High } \\
(76.25)\end{array}$ & $\begin{array}{l}\text { High } \\
(55)\end{array}$ & & L8 & $\begin{array}{c}\text { Salomar Beach } \\
(447848 \mathrm{E} / 4064843 \mathrm{~N})\end{array}$ & $\mathrm{G}$ & $\begin{array}{l}\text { High } \\
(70)\end{array}$ & $\begin{array}{l}\text { Very High } \\
(76.25)\end{array}$ & $\begin{array}{l}\text { Very High } \\
(86.25)\end{array}$ & $\begin{array}{l}\text { Very High } \\
(86.25)\end{array}$ \\
\hline & P2 & $\begin{array}{c}\text { Ancient Fluvial } \\
\text { Deposits } \\
(447383 \mathrm{E} / 4067687 \mathrm{~N})\end{array}$ & SD & $\begin{array}{l}\text { High } \\
(70)\end{array}$ & $\begin{array}{l}\text { High } \\
(71.25)\end{array}$ & $\begin{array}{l}\text { Very High } \\
\text { (78.75) }\end{array}$ & $\begin{array}{l}\text { High } \\
(68.75)\end{array}$ & & L9 & $\begin{array}{l}\text { Guadalfeo River Mouth } \\
\text { (448276E/4064364N) }\end{array}$ & G & $\begin{array}{l}\text { Moderate } \\
(48.75)\end{array}$ & $\begin{array}{c}\text { Very High } \\
(78.75)\end{array}$ & $\begin{array}{l}\text { Very High } \\
(81.25)\end{array}$ & $\begin{array}{l}\text { Very High } \\
(91.25)\end{array}$ \\
\hline & P3 & $\begin{array}{c}\text { Cemetery } \\
\text { Viewpoint }{ }^{\wedge *} \\
(446704 \mathrm{E} / 4067798 \mathrm{~N})\end{array}$ & $\mathrm{S}$ & $\begin{array}{l}\text { High } \\
(55)\end{array}$ & $\begin{array}{l}\text { Very High } \\
(82.5)\end{array}$ & $\begin{array}{l}\text { Very High } \\
(83.75)\end{array}$ & $\begin{array}{l}\text { High } \\
(63.75)\end{array}$ & & L10 & $\begin{array}{c}\text { Guadalfeo River } \\
(448386 \mathrm{E} / 4064559 \mathrm{~N})\end{array}$ & G & $\begin{array}{l}\text { High } \\
(66.25)\end{array}$ & $\begin{array}{l}\text { Very High } \\
(81.25)\end{array}$ & $\begin{array}{l}\text { Very High } \\
(83.75)\end{array}$ & $\begin{array}{l}\text { Very High } \\
(86.25)\end{array}$ \\
\hline
\end{tabular}

^* Viewpoint site according to Migón\&Pijet-Migón (2017);

H: Hidrogeology-hidrology; G: Geomophology; S: Structural; T: Stratigraphy; P: Petrography; GM: Geomaterials; SD: Sedimentology; M: Mineralogy

Table 1: Sites of Geological Interest (Geodiversity sites and Viewpoint sites) inventoried in the Salobreña area and their scores and thresholds. Typology: S: structural geology; SD: sedimentology; T: stratigraphy; P: petrography, G: geomorphology; H: hydrogeology-hydraulics; GM: geomaterials. SV: scientific value; PEU: potential educational use; PTU: potential touristic use; DR: degradation risk.
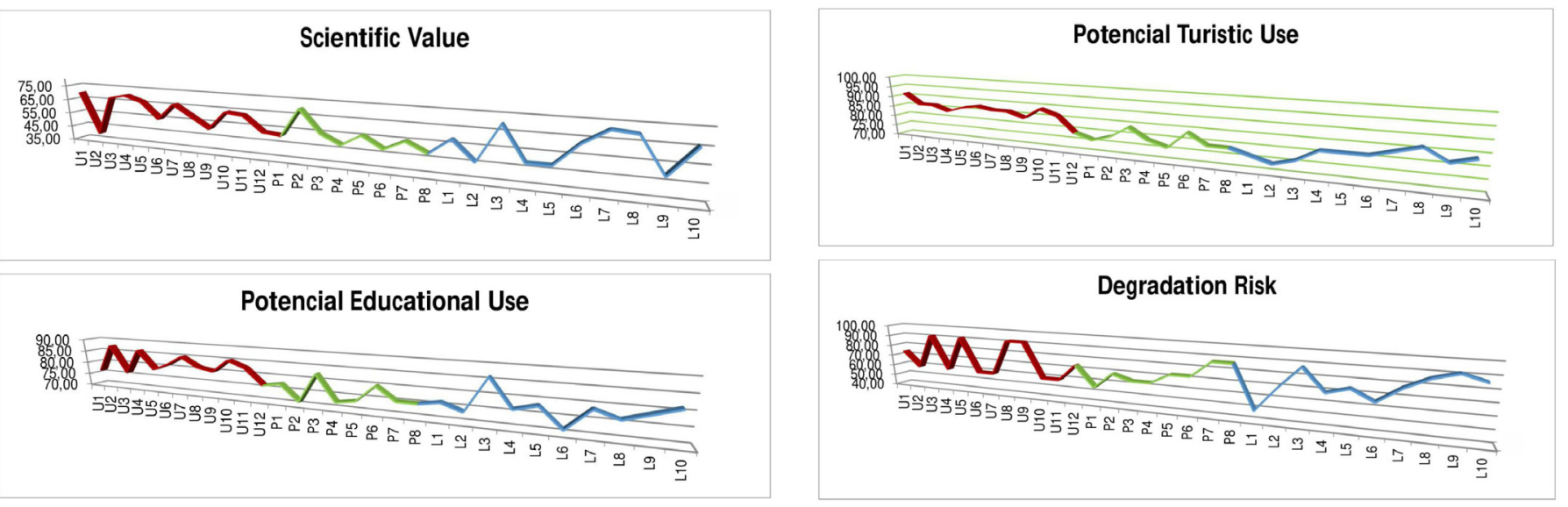

Figure 3: Profile representation of the SV, PEU, PTU and GR values for the 30 sites of geological interest 


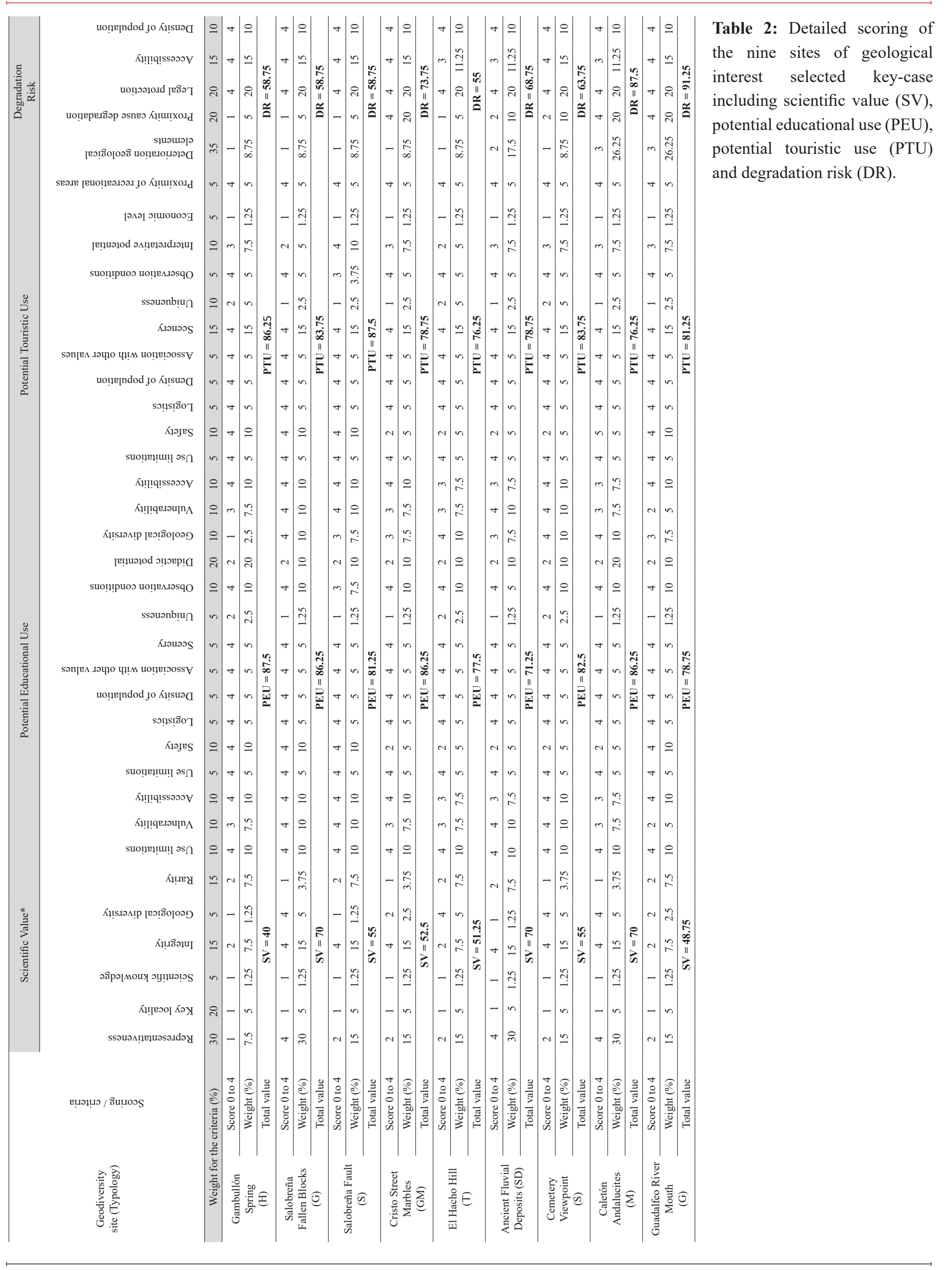




\section{Description and detailed scoring of 9 sites case study}

9 geodiversity sites have been selected for a detailed description in the following section (Tab. 2) giving an overview of the wealth in sites of geological interest (but little known by the general public) from the Salobreña area. The selected sites for this deep description show a variety of typologies among the most valuable sites from the 30 proposed. So, all the selected GD also has reached a value in PEU and PTE upper to 75. The location, description, figuration and/or graphic documentation and scoring or these case studies are developed in the following lines.

1) Gambullón spring $(447369 \mathrm{E} / 4066201 \mathrm{~N})$ is the site number U2. It belongs to the Urban Georoute and consists in a good example of the hydrogeology typology. The site is located to the base of the south side of the hill where the Salobreña old town is situated (Fig. 4A, 4B). The site is accessed via Mediterranean Avenue and, at the roundabout of the new La Fuente Park, taking the road to La Caleta. The site is at $250 \mathrm{~m}$ from the roundabout. Historically, the place corresponded with a pier for the mooring of ships in medieval times, since the sea reached the foot of the cliff (García-Consuegra, 2016). Later, when sea withdrew, it was the fresh water source for consumption by Salobreña town but the increase in population and problems of water contamination led to the discontinuation of use by humans. Its origin is related to the karstic and fissural aquifer of the marbles of the hill but also with interference of the detritic aquifer of the Guadalfeo Fan Delta (Duque, 2009). It shows a variable flow of between 10 and $100 \mathrm{l} / \mathrm{s}$ depending of the season (not drying up in dry periods). Nowadays it is used for irrigation of the crops in the plain between the hill and the beach. The scoring of this site (Tables 1 and 2) reveals a moderate SV (40). The PEU and the PTU are very high (87.5 and 86.25 , respectively). On another hand, the DR is high (58.75). The very high value of PEU and PTU make this site very important for educational, cultural and touristic purposes. The high value for DR makes it recommendable to plan for the protection of the site.

Near the Gambullón spring there is another one, La Raja spring, whose waters use the same channel but flow in an opposite direction. There where these two waters join, those of the Gambullón and Raja springs, they disappear into an underground canal.
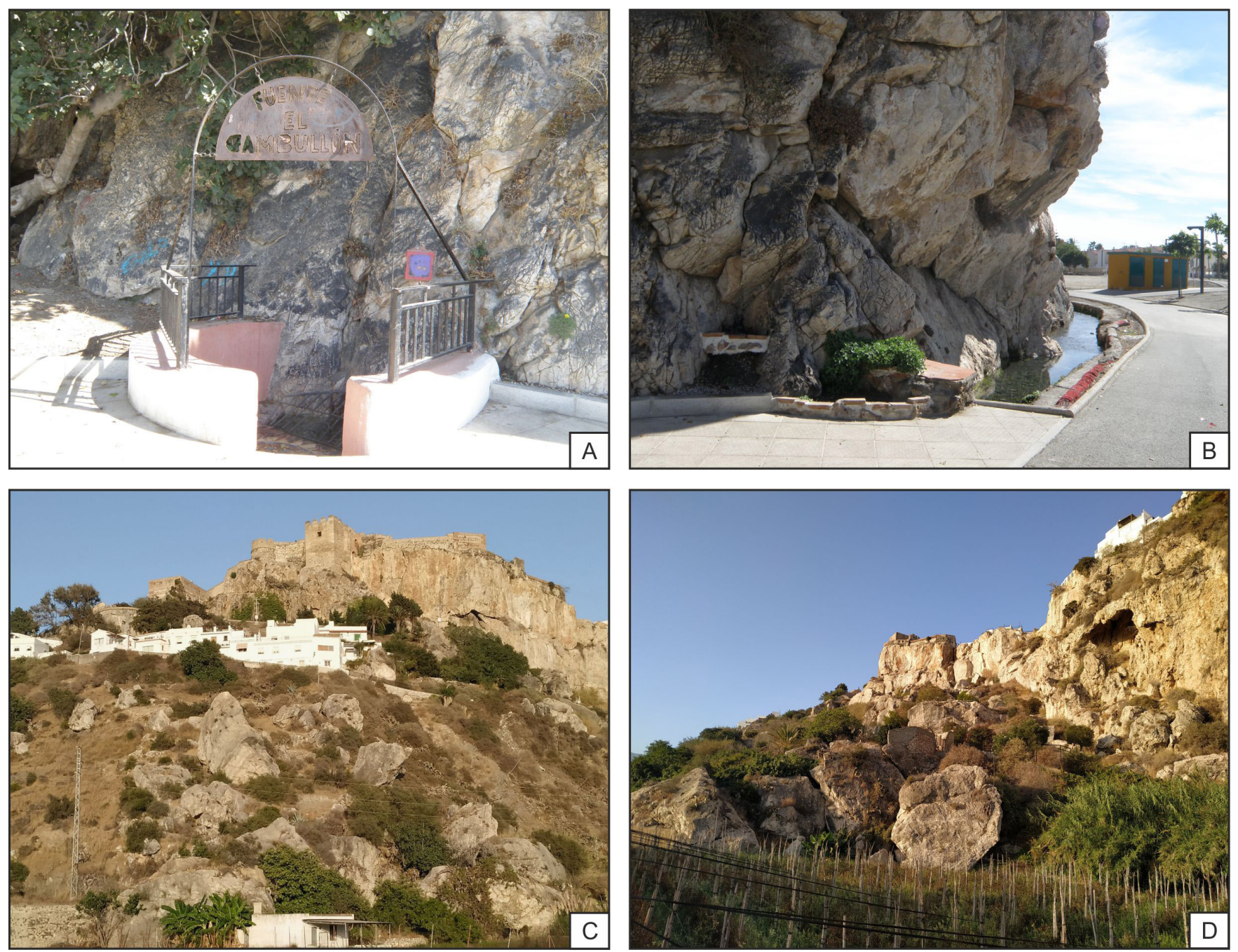

Figure 4: A. Gambullón spring; B.- Gambullón spring outflow; C. Salobreña fallen blocks; D. Detail of the fallen blocks. 
2) Salobreña Fallen Blocks $(447296 \mathrm{E} / 4066368 \mathrm{~N})$ is the site number U6 and also belongs to the Urban Georoute. It consists in a good example of the geomorphological Typology (gravitational instability phenomenon). The site is located to the west side of the Salobreña hill. The site is accessed via Mediterranean Avenue and, at the roundabout of the new La Fuente Park, taking the road to La Caleta. The site is $450 \mathrm{~m}$ from the roundabout. A spectacular rock fall phenomenon is visible in this site (Fig. 4C, 4D). Unstable blocks about to fall are also visible in the cliff. The fallen blocks reach the boundary of the crop areas. They affect historic constructions in the cliff such as an ancient path (the Moor path) and two watchtowers (Albarrana and Coracha Towers) both from the medieval era of Moors occupation (García-Consuegra,
2016). It is an area of high geological instability due to a vertical cliff and intense jointing affecting the marbles of the rocky massif. The constancy of this fragmentation by joints and faults favors the dislocation and individualization of tilted blocks to fall down. The scoring of this site (Tab. 2) reveals a high SV (70). The PEU and the PTU are also very high (96.25 and 91.25 , respectively). On another hand, the DR is high (58.75). The very high value of PEU and PTU make this site very important for educational, cultural and touristic purposes. The high value in SV makes it also interesting for researchers interested in gravitational instability processes. The high value for DR makes it advisable to plan for the protection of the site.
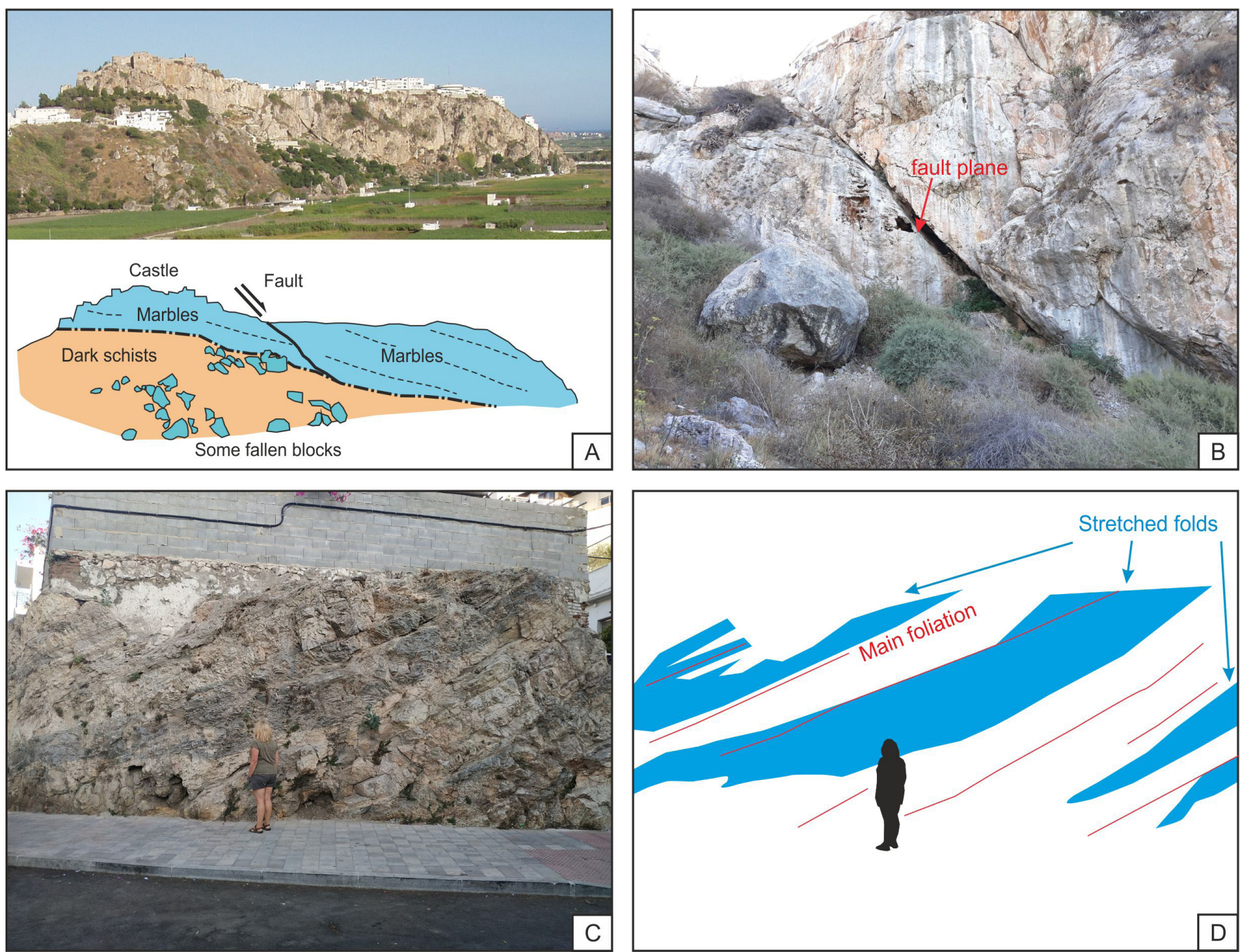

Figure 5: A. Panoramic view of the Salobreña hill and geological sketch interpretation with location of the Salobreña fault; B. Detail of the Salobreña plain fault; C. Calle Cristo marbles with bands of black and white colors; D. Interpretative sketch of the stretch folds and the main foliation in the marbles.

3) Salobreña Fault $(447341 \mathrm{E} / 4466531 \mathrm{~N})$ is the site number U6. It belongs to the Urban Georoute and is classified in the structural geology typology. The site is accessed from the former site, taking a steep ascending path to Paseo de las Flores at about $200 \mathrm{~m}$ and within this path, take a deviation towards the cliff. There, the fault is clearly visible affecting the marbles (Fig. 5A,B). It is a normal fault that favors the gravitational sliding of the marbles over the schists. In this aspect is a listric fault (its surface undergoes a very 
sharp change of dip). This is the reason why the two blocks of the fault have created an empty area between them. The scoring of this site (Tab. 2) reveals a moderate SV (55), very high PEU and the PTU values (91.25 and 87.5, respectively) and high DR (55.25). The very high value of PEU and PTU make very important this site for educational and touristic purposes, while the high value for DR makes advisable a plan for the protection of the site.

Finally, a recommendation for these two last points: in raining and windy days avoid this path, owing to the high risk of fallen of rocks.

4) Cristo Street Marbles (447733E/4066799N) is the site number $\mathrm{U} 12$, belongs to the geomaterials typology, and is the end point of the Urban Georoute. The site is located in the lower part of the urbanized area of Salobreña in the north side of the hill. In detail it is located at the crossing of the Cristo and Antonio Machado streets. It consists of an outcropping of the marbles of the hill of Salobreña where buildings are anchored (Fig. 5C, 5D). These marbles show the main foliation typical of metamorphic rocks and also some bands of change in composition of the marbles consisting in close and stretched folds. These rocks were historically used as building materials in old constructions, which gives them the typology of geomaterials. The scoring of this site (Tab. 2) reveals a moderate SV (52.5), very high PEU and the PTU values (86.25 and 83.75, respectively) and high DR (73.75). The very high value of PEU and PTU make this site very important for educational, cultural and touristic purposes, while the high value for DR makes it advisable to plan for the protection of the site.

5) El Hacho Hill $(447732 \mathrm{E} / 4067405 \mathrm{~N})$ is the site of geological interest number P1. This is the first site from the Panoramic Georoute and is a good example of the stratigraphy typology, but
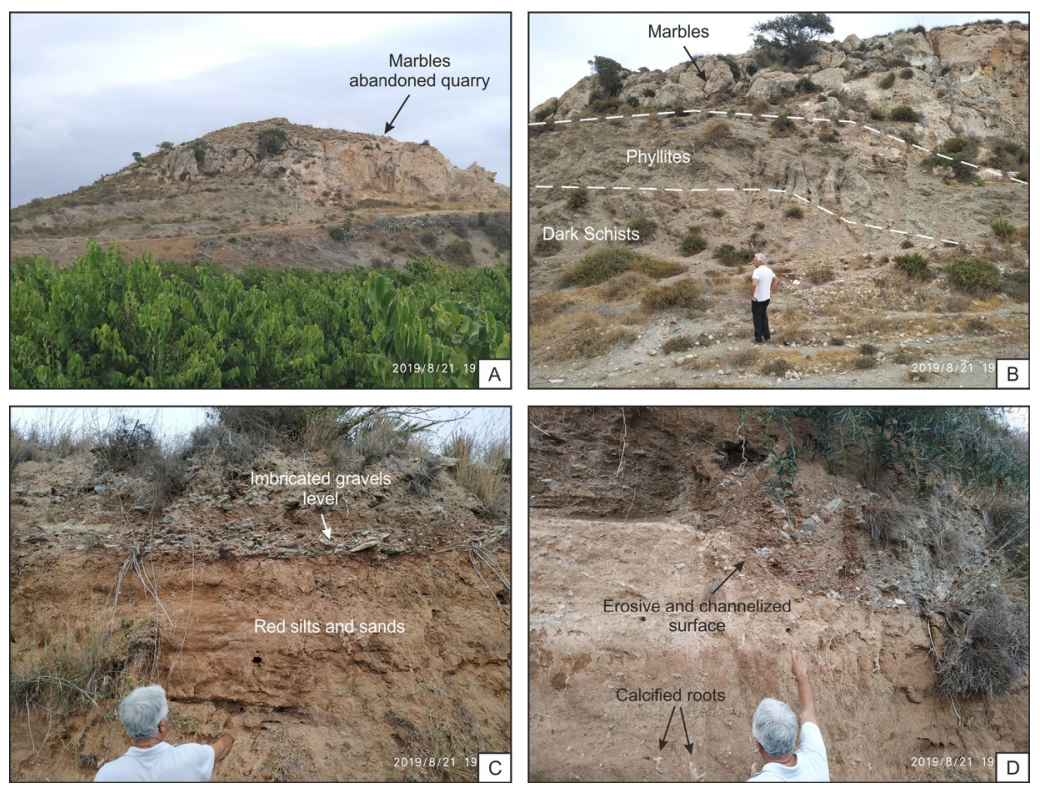

Figure 6: A. Panoramic view of the Hacho Hill; B. Detail of the stratigrahic level in the Hacho Hill; C. Ancient Guadalfeo fluvial deposits with imbricate gravels channel deposits and red fine flooding plain deposits; D. Detail of channelized surface associated to the gravel deposits, and calcified roots in the flooding plain deposits. 
6) Ancient Guadalfeo Fluvial Deposits (447383E/4067687N) is the site of geological interest number P1. This site belongs to the Panoramic Georoute and is a good example of the sedimentology. The site is accessed from the El Hacho Hill following the track of the irrigation channel level 25, and later, the ascension to Salobreña cemetery. The site is $500 \mathrm{~m}$ from the cemetery. In this site ancient fluvial deposits of the Guadalfeo River can be seen (Fig. 6C, 6D): red silt and sands from fluvial plain; imbricate gravels from fluvial channelized areas. Gravels levels, made of metamorphic rocks (schists, quartzite, marbles and green rocks), show erosive and channelized surfaces. The clasts imbrication indicates western flows. In the red silts and sands calcifications of plant roots are also visible. Comparable sediments are found to the N, near Molvízar, and are the testimony of a previous period of erosion of the surrounding reliefs and the deposits in the lower parts, particularly in the valley of the "proto" Guadalfeo River.

The scoring of this site (Tab. 2) reveals a high SV (70), very high PEU and the PTU values (81.25 and 78.75, respectively) and high DR (62.5). The very high value of PEU and PTU make this site very important for educational, cultural and touristic purposes, while the high value for DR makes it advisable to plan for the protection of the site.
7) Cemetery Viewpoint (446704E/4067798N) is the site of geological interest number P3. This site belongs to the Panoramic Georoute and is a viewpoint geodiversity site, good example of the structural geology typology. The site is located in the main access road from Salobreña to the cemetery; upward to the cemetery. A view of the Alpujarride nappe stacking, also folded in an anticlinal fold is visible in a first plane (Fig. 7A, 7B). From this point, and also in other points as is the Hacho Hill, the relief of the Escalate-Columba (Fig. 1 D) is visible. This relief corresponds to an anticline, thrust by schists of an Middle Alpujarride Unit. In this anticline Triassic marbles are visible in several places, as is the Vados area, in the channel of the Guadalfeo River, showing the Triassic phyllites situated under them. Further, to the NE, the Sierra the Lújar (Fig 1D) also present Triassic marbles which have a thickness greater than $1000 \mathrm{~m}$. Also, under these marbles (divided in several formations) there are phyllites. To the North, in the background, part of Sierra Nevada is visible, mainly formed (but not only) by Carboniferous dark schists. The scoring of this site (Tab. 2) reveals a moderate SV (55), very high PEU and the PTU values (92.5 and 93.75, respectively) and high DR (63.75). The very high value of PEU and PTU make this site very important for educational, cultural and touristic purposes, while the high value for DR makes it advisable to plan for the protection of the site.
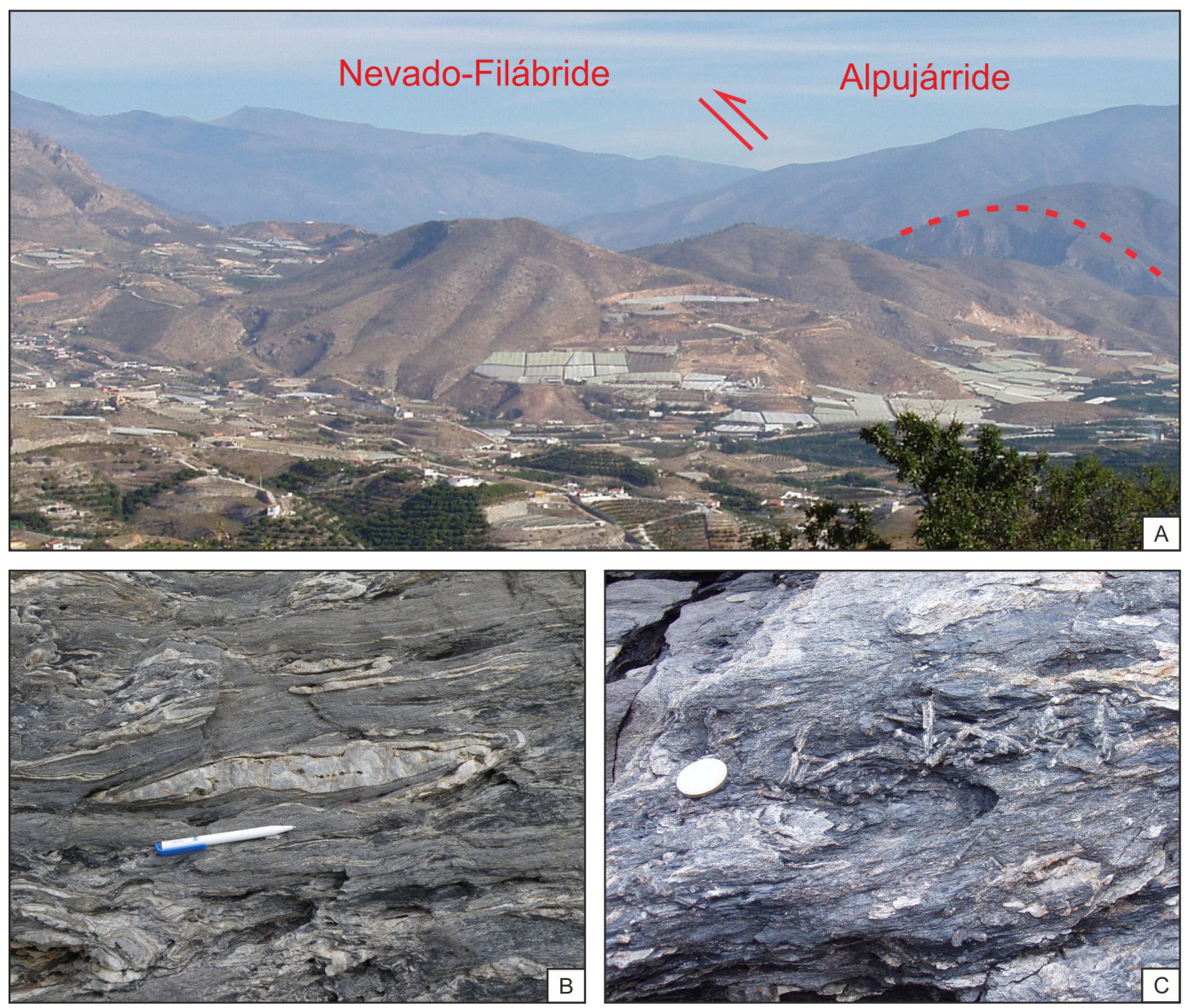

Figure 7: A. Panoramic view of the Sierra Nevada-Tajo los Vados area with some structural indication; B. Folded quartzitic veins in the schists of the Caletón area; C. Detail of Andalucite minerals in the Caletón area. 
8) Caletón Andalucites $(446141 \mathrm{E} / 4066682 \mathrm{~N})$ is the site of geological interest number L3. This site belongs to the Littoral Georoute and it has been assigned to the mineralogy typology. It is also a good example the folding undergone by the dark schists and quartzites. Particularly there (also from the Lavadero to the Caletón) these folds are very well formed, and have different sizes, from tens of meters to millimeters. There are two associated schistosities, the first intensely deformed. Also, the veins of quartz belonging to several generations, are intensely deformed. The site is accessed from a crosswalk (Ramblilla street) from La Caleta district to the Lavadero square and later following the Caletón path. The site is $25 \mathrm{~m}$ from the Lavadero square. In this site, from the Lavadero to the Caletón, in the schists and quartzites, andalucite minerals are visible (Fig. 7C, 7D). The presence of this mineral, generally not oriented, indicates a stage of high temperature and not high pressure (these rocks have been submitted to several stages of deformation during the orogenic stages). These rocks are also affected by many fractures, faults and joints. For this reason, together with the steep cliff existing there, the passage between the Lavadero to the Caletón, can be dangerous because many rocks, even blocks, can fall. For this reason, it is not recommended to use this path on windy or rainy days.

The scoring of this site (Tab. 2) reveals a high SV (70), very high PEU and the PTU values ( 86.25 and 76.25 , respectively) and very high DR (87.5). The very high value of PEU and PTU make this site very important for educational, cultural and touristic purposes.
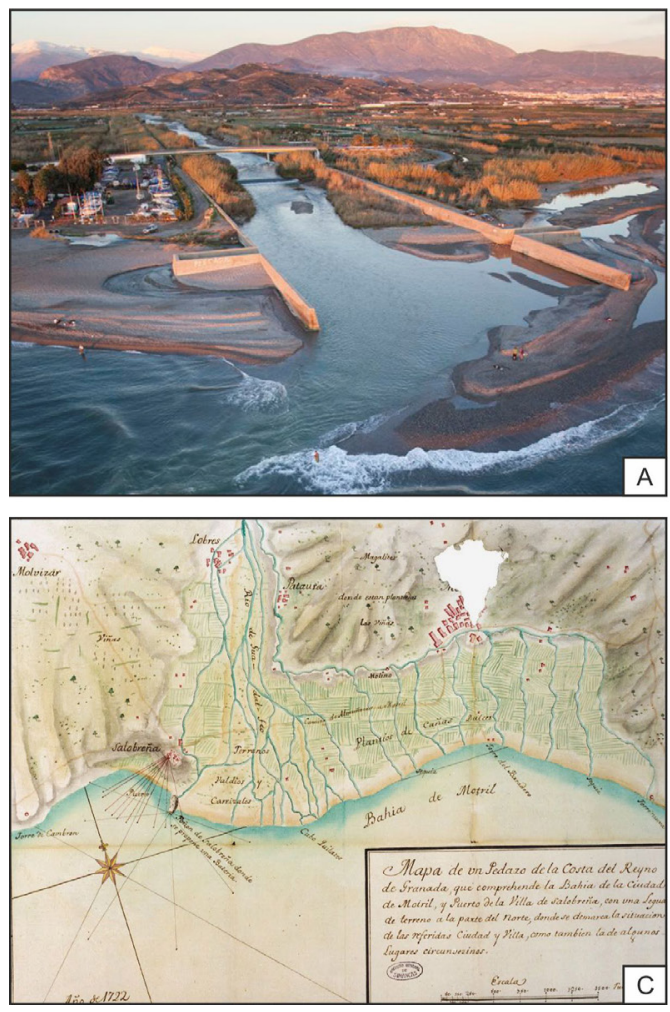

Also, the very high value for DR makes it essential to plan for the protection of the site.

9) Guadalfeo River Mouth (448276E/4064364N) is the site of geological interest number L9. This site belongs to the Litoral Georoute and is a good example of the geomorfology typology, but also sedimentology. The site is accessed from the beach or at the end of the seafront boulevard from Salobreña. In this site, the River Guadalfeo Mouth and the corresponding fan delta are visible. This site explains the growth of the fan delta from historical times and the littoral dynamics (Fig. 8). After several floods in the last centuries and unnecessary works from the $17^{\text {th }}$ century, the main channel was successfully moved and reinforced for $2.5 \mathrm{~km}$ to the present-day outlet in 1951 (Jabaloy-Sánchez et al., 2014). In the recent evolution of the delta some anthropic constructions have notoriously influenced the terrigeneous supply to the delta: the Béznar and Rules Dams. These dams regulate the $85 \%$ of the present total runoff of the river with a mean flow of $6.65 \mathrm{~m} 3 / \mathrm{s}$. Also, the Motril Harbor, located in the eastern termination of the delta, has a high influence in the marine coastal currents redistributing the sediments. The scoring of this site (Tab. 2) reveals a moderate SV (48.75), very high PEU and the PTU values (88.75 and 81.25, respectively) and very high DR (91.25). The very high value of PEU and PTU make this site very important for educational, cultural and touristic purposes. Also, the very high value for DR makes it essential to plan for the protection of the site.
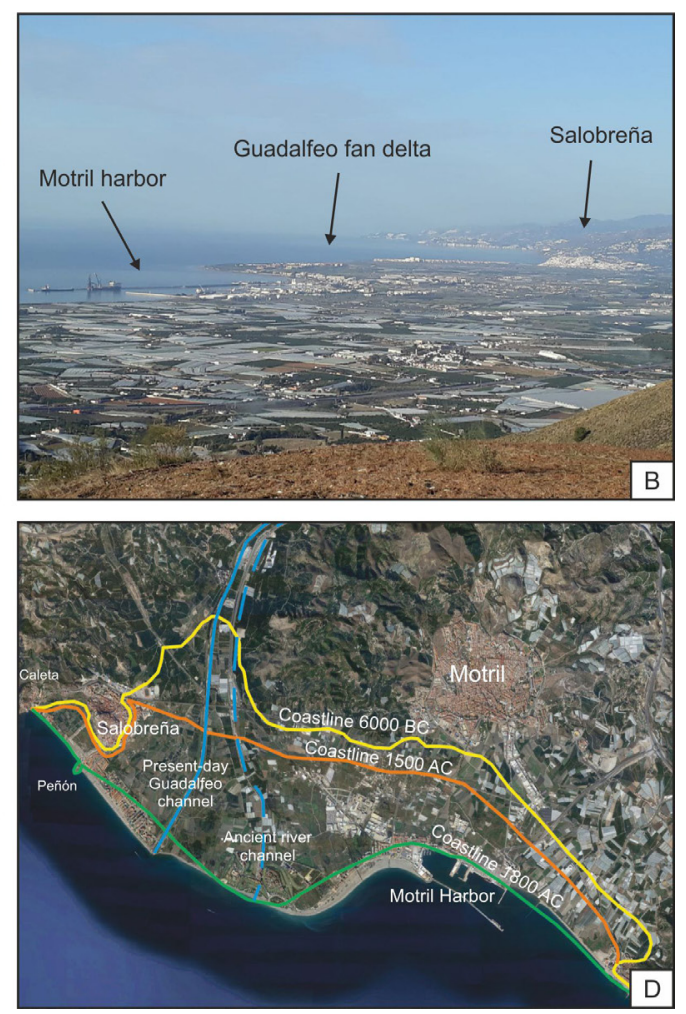

Figure 8: A. Guadalfeo River Mouth (photo from Junta de Andalucía: environmental report, 2013); B. Panoramic view of the Guadalfeo River fan delta; C. Historical map (año 1722) of the Guadalfeo fan delta; D Coastline evolution in the Guadalfeo deltaic system according to Jabaloy-Sánchez (2014). 


\section{Georoutes and their evaluations}

The proposed georoutes with the sites of geological interest are: Urban with 12, Panoramic with 8 and Littoral with 10, sites respectively. The Urban georoute, of about $2 \mathrm{~km}$ length, starts in the new La Fuente Park, follows the La Caleta road, ascension to the Paseo de los Flores by the Moor Path, Antequera street, Postigo viewpoint, Postigo descent, ending at the Cristo and Antonio Machado streets crossing. The Panoramic georoute, at about 5 kms length, starts at the roundabout in the western entrance of Salobreña, followed by the ascension to El Hacho Mount, track of the irrigation channel level 25, ascension to Salobreña cemetery, track of the irrigation channel level 100, descent to Almuñecar road (N340), sport area of La Caleta, ending in the chimney of the Guadalfeo Sugar Factory. The littoral georoute, at about $3.5 \mathrm{kms}$ length, starts in the Caletón beach, follows the Caletón path to the Lavadero square, breakwater of the Guadalfeo Sugar Factory, La Guardia beach, Salobreña beach, ending in the Guadalfeo River Mouth. These georoutes have also been quantified (Tab. 3) using the Bollati et al. $(2013,2017)$ modified. The SV mean value is high in all cases (values 61.6, 54.2 and 59.1, respectively). The PEU (81.4, 75.9, 77.7, respectively) and PTE (85.9, 79.4, 80.5, respectively) mean value are very high in all cases. On the contrary, the DR is high $(72.1,69.8,74.5$, respectively) in all cases (Fig. 9).

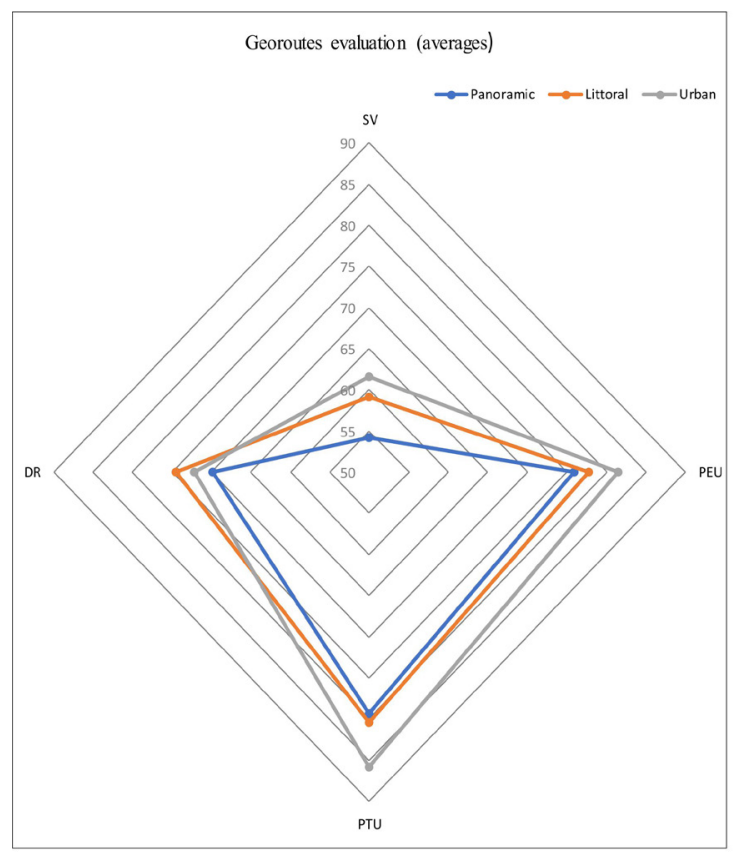

Figure 9: Polygon representation of the SV, PEU, PTU and GR values for the 3 georoutes.

\begin{tabular}{|c|c|c|c|c|c|c|c|c|c|c|c|c|c|c|}
\hline \multirow{2}{*}{$\begin{array}{l}\text { Georoutes } \\
\text { (number of } \\
\text { sites) }\end{array}$} & \multirow{2}{*}{$\begin{array}{l}\text { Length } \\
(\mathrm{km})\end{array}$} & \multirow{2}{*}{$\begin{array}{l}\text { Duration } \\
\text { time }\end{array}$} & \multicolumn{4}{|c|}{ Average values } & \multicolumn{8}{|c|}{ Typology and reference of the site } \\
\hline & & & SV & PEU & PTU & $\mathrm{DR}$ & $\mathrm{S}$ & $\mathrm{T}$ & $\mathrm{P}$ & G & $\mathrm{H}$ & SD & M & GM \\
\hline $\begin{array}{c}\text { Urban } \\
\text { (12 sites) }\end{array}$ & $2 \mathrm{~km}$ & $1 \mathrm{~h}$ & 61.6 & 81.4 & 85.9 & 72.1 & U6, U7, U9, U10 & U8 & & $\begin{array}{l}\text { U3, U4, U5, } \\
\text { U11 }\end{array}$ & U1, U2 & & & U12 \\
\hline $\begin{array}{l}\text { Panoramic } \\
\text { (8 sites })\end{array}$ & $5 \mathrm{~km}$ & $2 \mathrm{~h}$ & 54.2 & 75.9 & 79.4 & 69.8 & P3, P6, P8 & P1 & $\mathrm{P} 4$ & P5, P7 & & $\mathrm{P} 2$ & & \\
\hline $\begin{array}{l}\text { Littoral } \\
\text { (10 sites) }\end{array}$ & $3.5 \mathrm{~km}$ & $1 \mathrm{~h}$ & 59.1 & 77.7 & 80.5 & 74.5 & L1, L4 & & & $\begin{array}{l}\text { L2, L5, L6, L7, } \\
\text { L8, L9, L10 }\end{array}$ & & & L3 & \\
\hline
\end{tabular}

Table 3: Main characteristics (length, duration time, average values for SV, PEU, PTU and DR, and reference of the sites) of the 3 geo-routes

\section{Discussion and Conclusions}

The integrated measures of protection, education and sustainable development proposed by UNESCO in the Global Net of National Geoparks, as commented before, are the best way to protect an area containing sites of geological heritage.
These measures promote high quality standards in the services of the area, and also, the sharing of common strategies and best practice for conservation and development (Aoulad-Sidi-Mhend et al. 2019). Moreover, these concepts also allow the exchange of knowledge among areas with geological heritage around the globe (Eder and Patzak 2004; Zouros 2004; McKeever et al. 2010). The first step must be to perform an inventory of sites with scientific, educational and/or touristic relevance. This must be followed by a standard evaluation to prove the degree of importance with respect 
to the geological heritage, including the degradation risk (Brilha, 2016). This quantification should be of help to the political and technical managers of a region for preparing adequate geoconservation action plans.

Salobreña is an area which, in addition to a rich and remarkable touristic, climatic, agricultural and historical interest, presents a high geodiversity: landscapes, geomorphology aspects and a high number of sites of geological interest of different typologies (some examples of which are presented above). The quantitative assessment performed has provided 30 inventoried sites classified as Geodiversity Sites. The calculations have been performed following recent methodologies from literature (Bruschi and Cendrero 2009; Reynard 2009; Pereira and Pereira 2010; Bruschi et al. 2011; Pereira and Pereira 2012; Bollati et al. 2013, 2015,
2017, 2018; Brilha, 2016). Standard thresholds have been used in each part of the valorization (0-25 low, 26-50 moderate, 51-75 high, 76-100 very high). The low threshold is not found and the moderate one is much reduced among the proposed sites. The SV is, in the most of the cases, high, while the PEU and PTU are very high, in the most of the cases. The DR is mostly high with some cases very high and one moderate case (Table 1; Fig. 3).

These data prove that the geodiversity of the area is of enough relevance to be used with scientific, and mainly, educational and/ or touristic purposes. At the same time, the mentioned sites should be also preserved. Therefore, some general recommendations and advice for each category according to the thresholds obtained are tentatively suggested in Table 4.

\begin{tabular}{|c|c|c|c|c|}
\hline & Low & Moderate & High & Very High \\
\hline SV & $\begin{array}{c}\text { Not } \\
\text { applicable }\end{array}$ & $\begin{array}{l}\text { - Site not indicated for the } \\
\text { scientific community } \\
\text { - Site indicated for } \\
\text { educational-touristic } \\
\text { purposes }\end{array}$ & $\begin{array}{l}\text { - Site of interest for the } \\
\text { scientific community } \\
\text { - Site indicated for } \\
\text { educational-touristic } \\
\text { purposes }\end{array}$ & Not applicable \\
\hline PEU & $\begin{array}{c}\text { Not } \\
\text { applicable }\end{array}$ & Not applicable & $\begin{array}{l}\text { - Site indicated for } \\
\text { educational purposes }\end{array}$ & $\begin{array}{l}\text { - Site very indicated for } \\
\text { educational purposes } \\
\text { - Introduce signaling } \\
\text { systems } \\
\text { - Performing guides and } \\
\text { brochures } \\
\text { - promoting visits from } \\
\text { educational centers }\end{array}$ \\
\hline PTU & $\begin{array}{c}\text { Not } \\
\text { applicable }\end{array}$ & Not applicable & $\begin{array}{l}\text { - Site indicated for } \\
\text { touristic purposes }\end{array}$ & $\begin{array}{l}\text { - Site very indicated for } \\
\text { touristics purposes } \\
\text { - Introduce signaling } \\
\text { systems } \\
\text { - Performing guides and } \\
\text { brochures }\end{array}$ \\
\hline DR & $\begin{array}{c}\text { Not } \\
\text { applicable }\end{array}$ & $\begin{array}{l}\text { - Introduce regulatory } \\
\text { measures in the site }\end{array}$ & $\begin{array}{l}\text { - Introduce protection } \\
\text { and preservation } \\
\text { measures in the site }\end{array}$ & $\begin{array}{l}\text { - Visits controlled } \\
\text { and regulated by the } \\
\text { authorities }\end{array}$ \\
\hline
\end{tabular}

Table 4: Recommendations and advice for each category (SV, PTU, PTE and DR) according to the four thresholds (low, moderate, high and very high).

The proposed sites have been organized into three geo-routes which can be visited at the same time that the visitors take nice walks in which biosphere and landscape can also be enjoyed. The georoutes have also been quantified according to the methodology proposed by Bollati et al. (2013) obtaining equally very high mean values (Table 3, Fig. 9). This evaluation of the geo-routes can be used by visitors to choose the most suitable route (Bollati, 2013) according to their goals (scientific, educational or touristic). So, the Urban Georoute shows the highest mean values both for SV, PEU and PTU. On the contrary, the Panoramic Georoute shows the lowest mean values for those parameters. With respect to the DR, the Littoral Georoute shows the highest value and the Panoramic Georoute the lowest. 
In recent times, in addition to that from natural areas, valuable geo-heritage examples have been also defined in urban spaces (Palacio-Prieto, 2015). In the case of Spain, the urban geo-heritage of Alicante (Alfaro et al. 2004) and Segovia cities (Vegas and Díez-Herrero, 2018) were studied. In Europe, London (Robinson, 1982), Lisbon (Rodrigues et al., 2011), Paris (Auberger et al. 2016), Roma (Pica et al., 2016) Kracow and Prague (Chylinska and Kolodziejczyk, 2018), among others, have also been studied with the focus on the geological heritage. In the American continent, sites of geological interest were proposed for the Mexico City by Palacio-Prieto (2015) and for New York City by Merguerian and Sanders (1993). Also, in Karamay city, China (Jun-Ting et al., 2019), Darwing, Australia (McNally et al. 2010), and Africa, in Johannesburg (Thornbush and Allen, 2018), references to urban geo-heritage can be found. The above mentioned evidence the increasing interest of society in urban geological heritage. The geo-routes and sites of geological interest in the Salobreña area try to pay tribute to the geological heritage of this urban and touristic area.

\section{Final remarks and recommendations}

Some action can be proposed as follow in order to establish the bases of a sustainable development and to contribute, in a near future, to the establishment of an urban geopark in the Salobreña area (McKeever et al. 2010):

a) establishing a geological guide for the area with an inventory of the 30 sites of geological interest here proposed in order to promote this geological diversity.

b) implanting sustainable development projects (geo-tourism) by integrating the sites mentioned above, and others not mentioned in this paper, thus offering local people the opportunity to know this geological heritage.

c) organizing a signaling system for the sites on the access roads and paths, as well as, the situation of information boards at the points from which the sites can be observed.

d) developing the tourist office of the town with the possibility of obtaining guides and brochures with the information about the georoutes and the sites of geological interest, as well as, the exposition of explanatory panels on the geology of the Salobreña area.

e) promoting visits from educational centers (primary and secondary education, as well as, university) to the area. In these visits educational material should be given and seminars could be offered before the visits to the sites.

f) establishing awareness campaigns among the various stakeholders around the theme of preservation of this geological heritage, combined with strategies for sustainable development of the Salobreña area.

g) promoting this area from a sustainable geo-tourist point of view (cultural tourtism) by exploiting all the tools and methods such as information and communication technologies in order to illustrate the remarkable characteristics of the area.

The development of activities aimed to conserve and divulge the geological heritage of an area (usually undervalued) by the local-regional authorities and conservers of national parks can contribute to the improvement of the wealth of the region (Brilha, 2016). These georoutes with sites of geological interest will contribute to Education and promote Cultural Tourism. In the case of Education, these georoutes could be part of educational activities of local and regional schools and universities. In the case of Tourism, the development of georoutes with sites of geological interest can stimulate the visits of a different kind of tourist mostly interested in cultural aspects, but also complement the offer for the classical beach-summer tourists.

Aknowledgements Research supported by: Research Project CGL2016-75679-P, Spanish Ministry of Education and Science; Research Groups, Projects of the Generalitat Valenciana, Alicante University (CTMA-IGA), the project DAMAGE (AEI/FEDER CGL2016-80687-R) and the Spanish Seismic Hazard and Active Tectonics research group (RNM - 370). The English revision performed by Mr. Peter Donnelly is greatly acknowledged.

\section{References}

1. Alfaro, P., Andreu, J.M., Estévez, A., López-Arcos, M., Martín, I., Martín-Martín, M., Tent-Manclús, J.E., 2004. Patrimonio Geológico Urbano de Alicante. In: El Patrimonio Geológico: Cultura, Turismo y Medio Ambiente. GullénMondejar and Del Ramo Eds. 59-66

2. Auberger E, Gély J P, Merle D, De Wever P (2016) Geological heritage of the Ile-de-France region (France). Methodology of inventory, protection and valorization. Towards comparison with other European metropolises. Mémoires de la Soc. Géol Fr, 41-51

3. Aulad-Sidi-Mhend, A., Maaté, A., Amri, I., Hlila, R., Chakiri, S., Maaté, S., Martín-Martín, M. (2019) The Geological Heritage of the Talassemtane National Park-Ghomara coast Natural Area (NW of Morocco). Geoheritage, 11 (3): 10051025 .

4. Ayuntamiento de Salobreña. 2008. Guía botánica, Botanic walks, Concejalía de Medio Ambiente, 48 p.

5. Bollati I, Smiraglia C, Pelfini M (2013) Assessment and Selection of Geomorphosites and Trails in the Miage Glacier Area (Western Italian Alps). Environmental Management 51: 951-967 
6. Bollati I, Leonelli G, Vezzola L, Pelfini M (2015) The role of Ecological Value in Geomorphosite assessment for the Debris-Covered Miage Glacier (Western Italian Alpos) based on a review of 2.5 centuries of scientific study.Geoherigate 7 : 119-135

7. Bollati I, Crosa Lenz B, Zanoletti E, Pelfini M (2017) Geomorphological mapping for the valorization of the alpine environment. A methodological proposal tested in the Loana Valley (Sesia Val Grande Geopark, Western Italian Alps). Journal of Mountain Science 14(6): 1023-1038

8. Bollati I, Crosa Lenz B, Golzio A, Masseroli A (2018) Tree rings as ecological indicator of geomorphic activity in geoheritage studies. Ecological Indicators 93: 899-916

9. Brilha J (2016) Inventory and Quantitative Assessment of Geosites and Geodiversity Sites: a Review. Geoheritage 8: 119-134

10. Bruschi VM, Cendrero A(2009) Direct and parametric methods for theassessment of geosites and geomorphosites. In: Reynard E, Coratza P, Regolini-Bissig G (eds) Geomorphosites. Verlag Dr. Friedrich Pfeil, München. Section II, pp 73-88

11. Bruschi VM, Cendrero A, Albertos JAC (2011) A statistical approach to the validation and optimisation of geoheritage assessment procedures. Geoheritage 3(3):131-149

12. Chylinska, D, Kolodziejczyk K (2018) Geotourismin an urban space? Open Geosciences 10: 297-310

13. Duque, C. (2009). Influencia antrópica sobre la hidrogeología del acuífero Motril-Salobreña. Thesis Univ. Granada, Spain. $196 \mathrm{p}$.

14. Eder W, Patzak M (2004) Geoparks-geological attractions: a tool for public education, recreation and sustainable economic development. Episodes 27(3):162-164

15. El Gharbaoui A (1980) La Terre et l'Homme dans la péninsuleTingitane. Étude sur l'homme et le milieu natural dans le Rif occidental. PhD. Thesis, Paris University. 604 p

16. El Merzguioui M (2006) Projet de gestion durable et diversifiée des ressources naturelles et amélioration durable des conditions de vie des populations vulnérables dans les zones de hautes valeur écologiques du bassin versant de oued Laou. IVème Réunion internationale du projet Wadi Chefchaouen et Asilah. $42 \mathrm{p}$

17. Errami E, Schneider G, Ennih N, Randrianaly H N (2015) Geoheritage and Geoparks in Africa and Middle-East: Challenges and Perspectives. In: "From Geoheritage to Geoparks, Geoheritage, Geoparks and Geotourism” E. Errami et al. Eds. Springer. DOI 10.1007/978-3-319-10708-0_1. $1-22$.
18. Fuentes-Gutiérrez I, Fernández-Martínez E (2010) Geosites inventory in the Leon Province (Northwestern Spain): a tool to introduce geoheritage into regional environmental management. Geoheritage 2 (1-2): 57-75

19. Fuentes-Gutiérrez I, Fernández-Martínez E (2012) Mapping geosites for geoheritage management: a methodological proposal for the Regional Park of Picos de Europa (León, Spain). Environmental Management 50: 789-806

20. García-Consuegra Flores, J.E., 2016. Las atarazanas de la Salawbinya nazarí (Salobreña, Granada). Propuestas para su estudio arqueológico. Antiqvitas, 28, 165-173

21. Gensbol B (1984) Guide des rapaces diurnes d'Europe, d'Afrique du Nord et du Proche Orient. Delachaux\&Niestlé, Neuchâtel-Paris. 384p

22. Jabaloy-Sánchez, A., Lobo, F.J., Azor, A., Martín-Rosales W., Pérez-Peña, J.V., Bárcenas, P., Macías, J., Fernández-Salas, L.M., Vázquez-Vílchez, M. 2014. Six thousand years of coastline evolution in the Guadalfeo deltaic system (southern Iberian Peninsula). Geomorphology, 206, 374-391

23. Junta de Andalucía (2013): Monografías Medio Ambiente en Andalucía. La gestión litoral en Andalucía: normativa, estrategias y fuentes de información especializada. http://www. juntadeandalucia.es/medioambiente/site/ima/menuitem.

24. McKeever P, Zouros N, PatzakM,Weber J (2010) The UNESCO global network of national geoparks. In: Newsome D, Dowling R (eds) Geotourism: the tourism of geology and landscape. Goodfellow Publishers Ltd, Oxford, pp 221-230

25. McNally G H, Clarke G, Weber B W (2010) Porcellanite and the urban geology of Darwin, Northern Territory. Australian Jurnal of Earth Sciencies, 47: 35-44

26. Merguerian C, Sanders J E (1993) Trip 28 : Geology of southern Central Park, New York City. New York Academy of Sciences section of Geological Sciences Trips on the Rocks Guidebook. 143 p.

27. Migón P, Pijet-Migón E (2017) Viewpointgeosites - values, conservation and managements issus. Proceedings of the Geologists’ Association 128: 511-522

28. Palacio-Prieto, J.L., 2015. Geoheritage within cities: urban geosites in Mexico city. Geoheritage, 7 (4), 365-373

29. Pereira P, Pereira DI (2010) Methodological guidelines for geomorphosite assessment. Géomorphol Relief, Processus, Environ 2: 215-222

30. Pereira P, Pereira DI (2012) Assessment of geosites tourism value in geoparks: the example of Arouca Geopark (Portugal). Proceedings of the 11th European Geoparks Conference, Arouca: 231-232 
31. Pica, A., Vergari, F., Fredi, P., Del Monte, M., 2016 The AeternaUrbs Geomorphological Heritage (Rome, Italy). Geoheritage, 8 (1), 31-42

32. Jun-Ting Q, Liang Q, Hongxu M, Wenxin Y, Feng C, Bo-Kun Y, Jun-Chuan Y, He-Ming Y (2019). Geosites in Karamay city, Xinjiang Uygur Autonomous Region, northwest China. Geoheritage. 10.1007/s12371-019-00346-5.

33. Reynard E (2009) The assessment of geomorphosites. In: Reynard E, Coratza P, RegoliniBissig G (eds) Geomorphosites. Verlag Dr. Friedrich Pfeil, Munchen, pp 63-71

34. Robinson E (1984) A geological walk around the City of London - royal Exchange to Aldgate. Proceedings of the Geologists Association 93:225-246
35. Rodrigues, M.L., Machado, C.R., Freire, E., 2011. Geotourism routes in urban areas: a preliminary approach to the Lisbon Geoherigatte survey. GeoJournal of Tourism and Geosites, 2 (8), 281-294.

36. Thornbush M J, Allen D (2018) Urban geomorphology. Landforms and processes in cities. Elsevier 362 p.

37. Vegas J, Díez-Herrero A (2018) Best practice guidelines for the use of the geoheritage in the city of Segovia. IGME. 59 p.

38. Zouros N (2004) The European Geoparks Network. Geological heritage protection and local development. Episodes 27(3): 165-171

Citation: M. Martín-Martín1, C. Sanz de Galdeano and S. Moliner-Aznar “The Geological Heritage of Salobreña (South Spain): example of a touristic area”. American Research Journal of Humanities and Social sciences, Vol 2, Issue No. 1, 2021, pp. 1-17.

Copyright (c) 2021 M. Martín-Martín et al., This is an open access article distributed under the Creative Commons Attribution License, which permits unrestricted use, distribution, and reproduction in any medium, provided the original work is properly cited. 